\title{
Recent advances in the management of pediatric acute
}

\section{lymphoblastic leukemia [version 1; peer review: 2 approved]}

\author{
Jan Starý(D), Ondřej Hrušák
}

Department of Pediatric Hematology and Oncology, 2nd Faculty of Medicine, Charles University and University Hospital Motol, Prague, Czech Republic

V1 First published: 04 Nov 2016, 5(F1000 Faculty Rev):2635

https://doi.org/10.12688/f1000research.9548.1

Latest published: 04 Nov 2016, 5(F1000 Faculty Rev):2635

https://doi.org/10.12688/f1000research.9548.1

\section{Abstract}

Acute lymphoblastic leukemia (ALL) is the most common malignancy in childhood. Despite enormous improvement of prognosis during the last half century, ALL remains a major cause of childhood cancerrelated mortality. During the past decade, whole genomic methods have enhanced our knowledge of disease biology. Stratification of therapy according to early treatment response measured by minimal residual disease allows risk group assignment into different treatment arms, ranging from reduction to intensification of treatment. Progress has been achieved in academic clinical trials by optimization of combined chemotherapy, which continues to be the mainstay of contemporary treatment. The availability of suitable volunteer main histocompatibility antigen-matched unrelated donors has increased the rates of hematopoietic stem cell transplantation (HSCT) over the past two decades. Allogeneic HSCT has become an alternative treatment for selected, very-high-risk patients. However, intensive treatment burdens children with severe acute toxic effects that can cause permanent organ damage and even toxic death.

Immunotherapeutic approaches have recently come to the forefront in ALL therapy. Monoclonal antibodies blinatumomab and inotuzumab ozogamicin as well as gene-modified T cells directed to specific target antigens have shown efficacy against resistant/relapsed leukemia in phase I/II studies. Integration of these newer modalities into combined regimens with chemotherapy may rescue a subset of children not curable by contemporary therapy. Another major challenge will be to incorporate less toxic regimens into the therapy of patients with low-risk disease who have a nearly $100 \%$ chance of being cured, and the ultimate goal is to improve their quality of life while maintaining a high cure rate.

\section{Keywords}

paediatric, leukaemia, ALL, HSCT, immunotherapy, monoclonal antibodies

\section{Open Peer Review}

Approval Status

1 2

version 1

04 Nov 2016

Faculty Reviews are review articles written by the prestigious Members of Faculty Opinions. The articles are commissioned and peer reviewed before publication to ensure that the final, published version is comprehensive and accessible. The reviewers who approved the final version are listed with their names and affiliations.

1. Valentino Conter, University of Milano-

Biocca, Milan, Italy

\section{Stephen Sallan, Dana-Farber Cancer}

Institute, Boston, USA

Any comments on the article can be found at the end of the article. 
Corresponding author: Jan Starý (jan.stary@lfmotol.cuni.cz)

Competing interests: The authors declare that they have no competing interests.

Grant information: Supported by the project (Ministry of Health) for conceptual development of research organization 0006420 (University Hospital Motol, Prague, Czech Republic).

Copyright: @ 2016 Starý J and Hrušák O. This is an open access article distributed under the terms of the Creative Commons Attribution License, which permits unrestricted use, distribution, and reproduction in any medium, provided the original work is properly cited.

How to cite this article: Starý J and Hrušák O. Recent advances in the management of pediatric acute lymphoblastic leukemia

[version 1; peer review: 2 approved] F1000Research 2016, 5(F1000 Faculty Rev):2635 https://doi.org/10.12688/f1000research.9548.1

First published: 04 Nov 2016, 5(F1000 Faculty Rev):2635 https://doi.org/10.12688/f1000research.9548.1 


\section{Introduction}

Acute lymphoblastic leukemia (ALL) accounts for $25 \%$ of all childhood cancers and its outcome significantly influences the overall treatment results in pediatric oncology. The improvement of prognosis in childhood ALL is one of the most successful stories of modern medicine. An almost uniformly fatal disease at the beginning of the 1960s has transformed into a curable disorder in more than $90 \%$ of children with contemporary therapy. The major reason for improved survival is a decreased risk of relapse ${ }^{1,2}$. The outcome continues to improve at the beginning of the 21 st century. Moreover, this progress takes place not only in high-income countries but also in countries with limited resources because conventional chemotherapy is inexpensive and readily available worldwide ${ }^{3}$.

\section{Early response to treatment}

Since the beginning of the 2000s, patients have been stratified into risk groups according to the early treatment response evaluated by minimal residual disease (MRD). It has been determined by detection of aberrant leukemic phenotype by flow cytometry or by specific rearrangements of immunoreceptor genes IgH/TCR (heavy immunoglobulin/T-cell receptor $)^{4}$. MRD has been confirmed in multivariate analysis as the most significant prognostic factor within all immunophenotypes and genetic subgroups. MRD is first monitored during and at the end of induction ${ }^{5,6}$. Patients with a slow early response are stratified into the high-risk group. They profit from a more intensive post-induction treatment and augmented delayed intensification ${ }^{7-10}$. Rapid early responders to combined chemotherapy with B-cell precursor (BCP)-ALL benefit from early intensification of post-induction therapy, not from a prolonged double-delayed (augmented) intensification ${ }^{11,12}$. MRD performed about 3 months from diagnosis - that is, after early post-induction treatment-identifies a subset of patients with inferior outcome on Berlin-Frankfurt-Münster (BFM) protocols ${ }^{13,14}$. Treatment of T-cell (T)-ALL stratified according to treatment response has led to the excellent event-free survival (EFS) and overall survival (OS) of $85 \%$ and over $90 \%$, respectively ${ }^{15}$, although T-cell immunophenotype remains an adverse risk factor in multivariate analyses of clinical trials ${ }^{1,14}$. Stratification according to MRD response helps to improve prognosis of T-ALL patients in general but also in subsets, such as in the recently identified early T-cell precursor (ETP)-ALL. ETP-ALL patients tend to respond more slowly to induction therapy, and initial studies reported poor outcome ${ }^{16}$. When stratified according to MRD response, their outcome is comparable to those with non-ETP-ALL ${ }^{15,17}$.

\section{Contemporary therapy}

Optimization of standard chemotherapy in academic randomized clinical studies improves the outcome even at the beginning of the 21 st century. Substituting dexamethasone for prednisone for 3 weeks in the context of 2 years of BFM multi-agent therapy reduced the relapse risk by one-third ${ }^{18}$. On the other hand, dexamethasone also accounts for both long- and short-term side effects, many of which are dependent on dose intensity ${ }^{19}$. The immunosuppressive action of dexamethasone, alongside the use of anthracyclines, contributed to higher incidence of infection-related mortality compared with prednisone and thus resulted in no difference in OS between both arms. High-dose methotrexate $5 \mathrm{~g} / \mathrm{m}^{2}$ (HD MTX) in consolidation reduces bone marrow $(\mathrm{BM})$ and extramedullary relapses more efficiently than lower escalating doses of intravenous MTX without leucovorin rescue (followed by L-asparaginase, Capizzi regimen) in $\mathrm{BCP}-\mathrm{ALL}^{20}$. L-asparaginase has been a key component of all treatment regimens for childhood ALL since the 1960s. Its optimal dose, preparation, and route of administration remain uncertain ${ }^{21}$. Prolonged and intensified therapy with L-asparaginase improves the outcome of children with ALL. Administration of L-asparaginase can be hampered by allergic reactions. Clinical allergy is associated with inactivation of L-asparaginase by antibodies. Apart from overt allergy, antibodies can also cause a so-called silent inactivation, in which L-asparaginase is neutralized subclinically. Monitoring of L-asparaginase blood levels is useful because it detects silent inactivation $^{22}$. Pegylated Escherichia coli L-asparaginase (L-asparaginase coupled to polyethylene glycol) has a longer half-life and is potentially less immunogenic than native $E$. coli L-asparaginase and has been used with increasing frequency in frontline pediatric treatment regimens ${ }^{23}$. Following allergy to pegylated L-asparaginase, Erwinia L-asparaginase can be substituted and achieves therapeutic activity ${ }^{24}$.

Cranial irradiation is associated with a higher incidence of secondary malignancies and cognitive impairment in young children ${ }^{25,26}$. The use of dexamethasone, HD MTX, and intrathecal triple therapy in central nervous system (CNS) leukemia treatment has enabled reduction or even omission of cranial irradiation without compromising $\mathrm{OS}^{27,28}$. In a recently published meta-analysis, cranial radiotherapy (CRT) was associated with reduced risk of relapse only in patients with overt CNS leukemia at diagnosis ${ }^{29}$. Omission of CRT from childhood ALL therapy results in improved cognitive outcome. However, despite this improvement, survivors continue to demonstrate the elevated risk for attention deficits when compared with a reference population of children ${ }^{30}$.

The indication of hematopoietic stem cell transplantation (HSCT) in first complete remission (CR) is recommended for a subgroup of children (approximately 5\%) who are resistant to current chemotherapy (induction failure, persistent high MRD) ) $^{31,32}$.

Maintenance treatment with mercaptopurine and MTX is an integral part of ALL treatment. Lower adherence to oral mercaptopurine increases relapse risk ${ }^{33}$. The addition of vincristine plus steroid pulses in maintenance treatment still may be useful in cases where less intensive early therapy is used ${ }^{34}$. Children with intermediate-risk ALL who received intensive chemotherapy on the basis of BFM protocols did not benefit from intensification of the maintenance therapy with pulses of vincristine and dexamethasone ${ }^{35}$. Some subgroups of patients with unfavorable biology, like deletion of the gene for transcription factor $I K Z F 1$, might benefit from pulses during maintenance even on treatment with BFM backbone ${ }^{36}$.

\section{Treatment-related mortality}

The incidence of treatment-related mortality (TRM) on contemporary ALL trials is reported to be between 2 and 4\%. The most common cause of death is infection. The 5-year EFS of children with low-risk ALL who have favorable cytogenetics and good response to treatment is higher than $90 \%$, and death from TRM is as common as relapse. As such, reducing infection-related 
mortality is a paramount concern when improving outcomes in childhood ALL. Patients at highest risk of infection-related TRM are children older than 10 years, slow early responders, and those with Down syndrome (DS $)^{37,38}$. Lower socioeconomic status, noncompliance to therapy, and (in countries with limited resources) malnutrition all increase the risk of treatment failure ${ }^{39,40}$.

\section{Biologic and genetic features: targeted therapy}

Good risk prognostic genetic biomarkers of BCP-ALL are $t(12 ; 21)$ (ETV6-RUNX1) and high hyperdiploidy (51-65 chromosomes) $)^{41}$. Patients with either of these abnormalities have a 5-year OS of over 90\%. Five chromosomal abnormalities-MLL (KMT2A) translocations, t(9;22) (BCR-ABL1), t(17;19) (TCF3-HLF), near haploidy (fewer than 30 chromosomes), and low hypodiploidy (30-39 chromosomes) - are well-recognized prognostic biomarkers of high-risk disease at all ages ${ }^{42}$. Previously reported uniformly poor outcome of patients with hypodiploidy of less than 45 chromosomes might be improved by MRD-stratified treatment ${ }^{43}$. Approximately $30 \%$ of pediatric patients with BCP-ALL are screened negative for established diagnostic and prognostic markers. They are referred to as B-other ALL. Approximately $50 \%$ of B-other cases have a gene expression profile similar to that of BCR-ABL1-positive ALL. These cases form a subgroup that has been termed BCR-ABL1like or Ph-like ${ }^{44,45}$. They frequently harbor alterations of IKZFI or other B-lymphoid transcription factor genes. Stratification of these patients according to MRD helps to improve previously reported poor outcome of this subgroup ${ }^{46}$. Kinase-activating gene fusions detected in this subgroup are collectively found in 1 to $2 \%$ of BCP-ALL cases and can be targeted with tyrosine kinase inhibitors (TKIs $)^{47}$. Patients failing initial treatment might profit from the introduction of TKIs to high-risk chemotherapy. Up to 5\% of childhood ALL cases have JAK-STAT signaling pathway-activating fusions (CRLF2, JAK2, and EPOR), which appear to be targetable by JAK inhibitors ${ }^{48}$.

\section{Philadelphia chromosome-positive acute lymphoblastic leukemia}

HSCT has been the gold standard treatment for maintaining CR in Philadelphia chromosome-positive $\left(\mathrm{Ph}^{+}\right)$ALL since the 1990s; however, its importance may change in the era of TKIs. The onset of targeted therapy exemplified by TKIs has revolutionized the therapy of $\mathrm{Ph}^{+}$ALL. TKIs are introduced early in induction and continue through maintenance treatment. Length of treatment and cumulative dose of TKIs seems to play a role in the achievement of a better outcome ${ }^{49,50}$. MRD is considered to be essential for risk group stratification. Discrepancies in MRD using $I g H / T C R$ and BCR-ABL1 fusion indicate that lineages other than BCP may also be affected by the disease ${ }^{51}$. The best way to incorporate TKIs, conventional chemotherapy, and HSCT is still unclear. With current approaches, which are developed from high-risk protocols, acute toxicity is a significant problem. Future trials will examine the necessary chemotherapy dose intensity alongside TKI therapy and address in which subgroups HSCT is needed; with regard to TKIs, which agent to use, how long application should be, and what the role of post-HSCT is must be further investigated ${ }^{52}$.

\section{Clinical features: age and Down syndrome}

Most of the adolescents older than 15 years can be cured with riskadjusted intensive therapy without HSCT. They show higher rates of severe infections, osteonecrosis, thrombosis, and hyperglycemia $^{53,54}$. On the other hand, the outcome of infants younger than 1 year old is not improving. MLL gene rearrangement, which is associated with chemoresistance to conventional chemotherapy, is present in $80 \%$ of them. Their leukemic cells display a global hypermethylated genomic state. It explains remarkable sensitivity to demethylating agents ${ }^{55}$. Their potential to improve the outcome of the infant ALL cases will be verified in clinical trials.

Children with DS-ALL have a higher cumulative incidence of relapses and therapy-related mortality (infectious deaths) than nonDS patients. They have low incidence of prognostically advantageous genetic subtypes (ETV6-RUNX1 fusion, hyperdiploidy 51-65 chromosomes). Higher risk of toxic complications puts pressure on physicians to reduce the treatment intensity in DS-ALL. However, even in DS, unmodified risk-adjusted ALL treatment, combined with good supportive care, is indicated ${ }^{56}$.

\section{Leukemias of ambiguous lineage}

Up to $5 \%$ of acute leukemia cases present with some kind of lineage ambiguity. Among the four subsets of ambiguous lineage leukemias, the most prevalent are those classified by the presence of too many phenotype features of the opposite lineage (ALL versus acute myeloid leukemia). The existing definitions are arbitrary and sometimes are criticized for including too few markers (the World Health Organization definition, now most widely used) or too many markers (the previous EGIL-European Group for the Immunological Classification of Leukemias-definition) ${ }^{57,58}$. Irrespective of the definition, the prognosis of children with this type of ambiguity was slightly poorer when compared with other cases receiving the same treatment ${ }^{59,60}$. Much rarer subtypes are bilineal (biclonal) leukemias, in which two or more clones belonging to different lineages coexist at diagnosis. Interestingly, emerging studies show that despite phenotypic differences, the two clones often share genetic features (61 and Thomas Alexander, personal communication). A third subtype, also uncommon, is the undifferentiated leukemia. Patients with this subset do not fulfill the existing criteria for ALL or for acute myeloid leukemia. In such situations, infiltration of hematopoietic organs by another malignancy should always be considered. The fourth subtype is represented by leukemias that change their phenotype from one lineage to another during the beginning of treatment. Historically, this feature has mostly been referred to as being associated with MLL rearrangements or $\mathrm{BCR} / \mathrm{ABL1} 1^{62}$. More recently, lineage switching toward monocytic lineage has been described mostly in ALLs with aberrant $\mathrm{CD} 2$ at presentation ${ }^{63}$. This phenomenon is present in varying degrees in up to $4 \%$ of BCP-ALL cases and is mostly temporary, not requiring major changes of treatment; however, monocytosis as well as monocytoid organ infiltration may be clinically significant, and development into monocytic leukemia has been observed in one case ${ }^{63}$. Besides CD2, such "swALL" cases are associated with changes in CEBPA methylation ${ }^{63}$ and overlap with 
ERG-deleted ALLs ${ }^{64}$. Overall, owing to their rarity, ambiguous lineage leukemias should be studied cooperatively. An international study currently taking place addresses the treatment outcome of over 270 cases and their molecular background and aims to find the causal factors as well as optimal treatments ${ }^{65}$.

\section{Relapsed acute lymphoblastic leukemia}

Relapse is diagnosed in fewer than $15 \%$ of children. Relapsed disease tends to be more drug resistant than is newly diagnosed ALL, as shown by lower disease clearance and reduced CR rate, especially in early relapses ${ }^{66,67}$. When diagnosed, most ALL cases are oligoclonal. A patient's sensitivity or resistance to therapy is affected by genetic variations in individual subclones, and these can influence a subsequent clonal evolution during treatment as well $^{68}$. Major diagnostic clone at diagnosis is eradicated by chemotherapy in the majority of cases. A substantial part of relapsed ALL cases arise from minor subclones already present at diagnosis. Some abnormalities gained under chemotherapy pressure confer resistance to important components of combined chemotherapy, like nucleoside analogues (NT5C2, PRPS1 mutations) and glucocorticoids (CREBBP mutation) $)^{69-72}$. Despite this, the optimization of combined chemotherapy might improve the outcome. The UK ALL R3 randomized trial for patients in first relapse compared two anthracyclines, mitoxantrone and idarubicin, in induction. Relapse incidence was significantly lower in the group treated with mitoxantrone and translated into a clear survival advantage of more than $20 \%$, one of the largest improvements ever achieved by a single drug. Surprisingly, no difference in MRD could be detected between two randomized groups. Three-year OS was $69 \%$ in the mitoxantrone group $^{73}$. The most frequent type of relapse is late BM relapse, more than 6 months from completion of treatment in BCP-ALL. Contemporary chemotherapy combined with HSCT in MRD poor responders to induction treatment is able to cure $70 \%$ of children ${ }^{74}$. In this group, deletion of IKZFI transcription factor and alteration of TP53 identify patients with significantly inferior outcome ${ }^{75}$. The outcome of early BM relapses of BCP-ALL (during treatment or less than 6 months from the completion of treatment) and all $\mathrm{BM}$ relapses of T-ALL is worse. HSCT is indicated in all of these patients achieving remission. Only one-third of them are cured ${ }^{76}$. Deletion of $I K Z F 1$ is strongly predictive of a second relapse after $\mathrm{HSCT}^{75}$. IKZFI and TP53 represent relevant prognostic factors that should be considered in the assessment of children with relapsed ALL. The outcome of isolated and combined extramedullary relapses depends on the interval between diagnosis and relapse. HSCT may improve the outcome of those with highest risk.

The results of allogeneic HSCT are steadily improving. There is no difference in outcome between HSCT from matched sibling donors (MSDs) and unrelated main histocompatibility antigenidentical 9-10/10 volunteers (matched unrelated donor [MUD]). Transplant-related mortality is now below $10 \%$ in MSD and $20 \%$ in MUD HSCT. The likelihood of being cured by HSCT performed in second remission is about $60 \%{ }^{31}$. Standard conditioning regimens include total body irradiation, which is associated with significant risk of secondary cancer. Substituting chemotherapy for total body irradiation is currently being evaluated by a randomized study.

\section{Immunotherapy}

The intensity of current front-line therapy has reached its threshold. Further intensification is not realistic. The majority of children with early BM relapse currently have little chance to be cured. There is growing evidence that targeted treatment and immunotherapy have the potential to improve the outcome of childhood ALL with reduced toxicity. A novel method of cellular therapy is based on the use of adoptively transferred $\mathrm{T}$ lymphocytes which were modified in vitro prior to transfer to express an artificial signaling molecule designated chimeric antigen receptor (CAR). The CAR redirects the specificity of the modified $\mathrm{T}$ lymphocytes to surface antigens expressed by malignant cells. The most successful example of CAR-based immunotherapy is the treatment of BCPALL by targeting of the surface antigen CD19. In a pilot study, CR was achieved in $90 \%$ of 30 children and adults with highly refractory disease ${ }^{77}$. CAR cells can cross the blood-brain barrier and eliminate leukemic cells in the cerebrospinal fluid. CAR cells of the third generation are able to engraft and persist for at least several months ${ }^{78}$. The most common acute toxicity of CAR T cells is cytokine release syndrome. A wide variety of cytokines, including interleukin-6, interferon-gamma, and tumor necrosis factor, are elevated in the serum of patients experiencing fever, tachycardia, hypotension, and other toxicities. Higher disease burden predicts more toxicity. The interleukin-6 receptor antagonist tocilizumab is widely used for toxicity following CAR infusion ${ }^{79}$. Randomized studies are needed to demonstrate whether they will be able to substitute HSCT.

Blinatumomab, a bi-specific anti-CD19/CD3 chimeric antibody, draws malignant $\mathrm{B}$ cells in close proximity to $\mathrm{CD} 3$-positive $\mathrm{T}$ cells. Activated $\mathrm{T}$ cells effectively induce serial target cell killing. In current clinical trials, blinatumomab is administered over a 28-day continuous infusion, followed by a 14-day rest period. In a phase I/II study of blinatumomab in children, objective responses were noted in $43 \%$ patients, including negative MRD in $39 \%$ of patients. Optimal placement of immunotherapy with blinatumomab or other conventional immunomodulating approaches or both has yet to be determined ${ }^{80,81}$.

The anti-CD22 immunoconjugate inotuzumab ozogamicin is an antibody-drug conjugate, consisting of humanized anti-CD22 monoclonal antibody joined to the cytotoxic agent calicheamicin by a non-immunogenic linker. After inotuzumab calicheamicin binds to CD22, rapid internalization of the conjugated calicheamicin occurs, targeting tubulin and inducing DNA breakage, apoptosis, and cell death. The response rate in adults with refractory/relapsed ALL is $80 \%$, and clinical studies in children were launched recently ${ }^{82}$.

\section{Conclusions}

Despite advances in targeted therapy approaches, conventional chemotherapy is unlikely to be replaced and this is because of its impressive cure rate in ALL. The task in coming years will be to compare immunotherapy with standard chemotherapy on a randomized basis in frontline treatment and in the treatment of first relapse. The goals are to also cure those children in whom combined chemotherapy fails and to reduce the toxicity that is responsible for reducing the quality of life for those who are cured. 


\section{Abbreviations}

ALL, acute lymphoblastic leukemia; BCP, B-cell precursor; BCP-ALL, B-cell precursor acute lymphoblastic leukemia; BFM, Berlin-Frankfurt-Münster (study group); BM, bone marrow; CAR, chimeric antigen receptor; CNS, central nervous system; CR, complete remission; CRT, cranial radiotherapy; DS, Down syndrome; DS-ALL; acute lymphoblastic leukemia in children with Down syndrome; EFS; event-free survival; ETP, early T-cell precursor; ETP-ALL, early T-cell precursor acute lymphoblastic leukemia; HD, high-dose; HSCT, hematopoietic stem cell transplantation; IgH/TCR, heavy immunoglobulin/T-cell receptor; MRD, minimal residual disease; MSD, matched sibling donor; MTX, methotrexate; MUD, matched unrelated donor; OS, overall survival; $\mathrm{Ph}^{+}$ALL, Philadelphia chromosome-positive acute lymphoblastic leukemia; T-ALL, T-cell acute lymphoblastic leukemia; TKI, tyrosine kinase inhibitor; TRM, treatment-related mortality.

\section{Competing interests}

The authors declare that they have no competing interests.

\section{Grant information}

Supported by the project (Ministry of Health) for conceptual development of research organization 0006420 (University Hospital Motol, Prague, Czech Republic).
1. Hunger SP, Lu X, Devidas M, et al.: Improved survival for children and adolescents with acute lymphoblastic leukemia between 1990 and 2005: a report from the children's oncology group. J Clin Oncol. 2012; 30(14): 1663-9. PubMed Abstract | Publisher Full Text | Free Full Text

2. Pui $\mathrm{CH}$, Pei $\mathrm{D}$, Campana $\mathrm{D}$, et al:: A revised definition for cure of childhood acute lymphoblastic leukemia. Leukemia. 2014; 28(12): 2336-43. PubMed Abstract | Publisher Full Text | Free Full Text

3. Stary J, Zimmermann M, Campbell M, et al:: Intensive chemotherapy for childhood acute lymphoblastic leukemia: results of the randomized intercontinental trial ALL IC-BFM 2002. J Clin Oncol. 2014; 32(3): 174-84. PubMed Abstract | Publisher Full Tex

4. van Dongen JJ, van der Velden VH, Brüggemann $\mathrm{M}$, et al.: Minimal residual disease diagnostics in acute lymphoblastic leukemia: need for sensitive, fast, and standardized technologies. Blood. 2015; 125(26): 3996-4009. PubMed Abstract | Publisher Full Text | Free Full Text

5. Flohr T, Schrauder A, Cazzaniga G, et al:: Minimal residual disease-directed risk stratification using real-time quantitative PCR analysis of immunoglobulin and T-cell receptor gene rearrangements in the international multicenter trial AIEOP-BFM ALL 2000 for childhood acute lymphoblastic leukemia. Leukemia. 2008; 22(4): 771-82.

PubMed Abstract | Publisher Full Tex

6. Borowitz MJ, Wood BL, Devidas M, et al.: Prognostic significance of minimal residual disease in high risk B-ALL: a report from Children's Oncology Group study AALL0232. Blood. 2015; 126(8): 964-71. PubMed Abstract | Publisher Full Text | Free Full Text

7. Nachman JB, Sather HN, Sensel MG, et al:: Augmented post-induction therapy for children with high-risk acute lymphoblastic leukemia and a slow response to initial therapy. N Engl J Med. 1998; 338(23): 1663-71.

PubMed Abstract | Publisher Full Text

8. Seibel NL, Steinherz PG, Sather HN, et al:: Early postinduction intensification therapy improves survival for children and adolescents with high-risk acute lymphoblastic leukemia: a report from the Children's Oncology Group. Blood. 2008; 111(5): 2548-55.

PubMed Abstract | Publisher Full Text | Free Full Text

9. Lange BJ, Bostrom BC, Cherlow JM, et al:: Double-delayed intensification improves event-free survival for children with intermediate-risk acute lymphoblastic leukemia: a report from the Children's Cancer Group. Blood. 2002; 99(3): 825-33.

PubMed Abstract | Publisher Full Text

10. Vora A, Goulden N, Mitchell C, et al:: Augmented post-remission therapy for a minimal residual disease-defined high-risk subgroup of children and young people with clinical standard-risk and intermediate-risk acute lymphoblastic leukaemia (UKALL 2003): a randomised controlled trial. Lancet Oncol. 2014; 15(8): 809-18.

PubMed Abstract | Publisher Full Text

11. Matloub $\mathrm{Y}$, Bostrom $\mathrm{BC}$, Hunger SP, et al: Escalating intravenous methotrexate improves event-free survival in children with standard-risk acute lymphoblastic leukemia: a report from the Children's Oncology Group. Blood. 2011; 118(2): 243-51.

PubMed Abstract | Publisher Full Text | Free Full Text

12. Vora A, Goulden N, Wade R, et al: Treatment reduction for children and young adults with low-risk acute lymphoblastic leukaemia defined by minimal residual disease (UKALL 2003): a randomised controlled trial. Lancet Oncol. 2013; 14(3): 199-209.

PubMed Abstract | Publisher Full Text
13. F Conter V, Bartram CR, Valsecchi MG, et al:: Molecular response to treatment redefines all prognostic factors in children and adolescents with B-cell precursor acute lymphoblastic leukemia: results in $\mathbf{3 1 8 4}$ patients of the AIEOP-BFM ALL 2000 study. Blood. 2010; 115(16): 3206-14. PubMed Abstract | Publisher Full Text | F1000 Recommendation

14. F Schrappe M, Valsecchi MG, Bartram CR, et al.: Late MRD response determines relapse risk overall and in subsets of childhood T-cell ALL: results of the AIEOP-BFM-ALL 2000 study. Blood. 2011; 118(8): 2077-84. PubMed Abstract | Publisher Full Text | F1000 Recommendation

15. Wood BL, Winter SS, Dunsmore KP, et al.: T-Lymphoblastic Leukemia (T-ALL) Shows Excellent Outcome, Lack of Significance of the Early Thymic Precursor (ETP) Immunophenotype, and Validation of the Prognostic Value of EndInduction Minimal Residual Disease (MRD) in Children's Oncology Group (COG) Study AALL0434. Blood. 2014; 124(21): 1. Reference Source

16. Coustan-Smith E, Mullighan CG, Onciu M, et al:: Early T-cell precursor leukaemia: a subtype of very high-risk acute lymphoblastic leukaemia. Lancet Oncol. 2009; 10(2): 147-56

PubMed Abstract | Publisher Full Text | Free Full Text

17. F Conter V, Valsecchi MG, Buldini B, et al:: Early T-cell precursor acute lymphoblastic leukaemia in children treated in AIEOP centres with AIEOPBFM protocols: a retrospective analysis. Lancet Haematol. 2016; 3(2): e80-6. PubMed Abstract | Publisher Full Text | F1000 Recommendation

18. F Möricke A, Zimmermann M, Valsecchi MG, et al.: Dexamethasone vs prednisone in induction treatment of pediatric ALL: results of the randomized trial AIEOP-BFM ALL 2000. Blood. 2016; 127(17): 2101-12. PubMed Abstract | Publisher Full Text | F1000 Recommendation

19. F Jackson RK, Irving JA, Veal GJ: Personalization of dexamethasone therapy in childhood acute lymphoblastic leukaemia. Br J Haematol. 2016; 173(1): 13-24. PubMed Abstract | Publisher Full Text | F1000 Recommendation

20. F Larsen EC, Devidas M, Chen S, et al:: Dexamethasone and High-Dose Methotrexate Improve Outcome for Children and Young Adults With High-Risk B-Acute Lymphoblastic Leukemia: A Report From Children's Oncology Group Study AALL0232. J Clin Oncol. 2016; 34(20): 2380-8.

PubMed Abstract | Publisher Full Text | Free Full Text | F1000 Recommendation

21. Pieters $\mathrm{R}$, Hunger $\mathrm{SP}$, Boos $\mathrm{J}$, et al:: L-asparaginase treatment in acute lymphoblastic leukemia: a focus on Erwinia asparaginase. Cancer. 2011; 117(2): 238-49.

PubMed Abstract | Publisher Full Text | Free Full Text

22. $\mathrm{F}$ Tong $\mathrm{WH}$, Pieters $\mathrm{R}$, Kaspers GJ, et al: A prospective study on drug monitoring of PEGasparaginase and Erwinia asparaginase and asparaginase antibodies in pediatric acute lymphoblastic leukemia. Blood. 2014; 123(13): 2026-33. PubMed Abstract | Publisher Full Text | Free Full Text | F1000 Recommendation

23. F Place AE, Stevenson KE, Vrooman LM, et al.: Intravenous pegylated asparaginase versus intramuscular native Escherichia coli L-asparaginase in newly diagnosed childhood acute lymphoblastic leukaemia (DFCI 05-001): a randomised, open-label phase 3 trial. Lancet Oncol. 2015; 16(16): 1677-90. PubMed Abstract | Publisher Full Text | F1000 Recommendation

24. Salzer WL, Asselin B, Supko JG, et al:: Erwinia asparaginase achieves therapeutic activity after pegaspargase allergy: a report from the Children's Oncology Group. Blood. 2013; 122(4): 507-14. PubMed Abstract | Publisher Full Text | Free Full Text 
25. Schmiegelow K, Levinsen MF, Attarbaschi A, et al:: Second malignant neoplasms after treatment of childhood acute lymphoblastic leukemia. J Clin Oncol. 2013; 31(19): 2469-76

PubMed Abstract | Publisher Full Text | Free Full Text

26. F Cheung YT, Krull KR: Neurocognitive outcomes in long-term survivors of childhood acute lymphoblastic leukemia treated on contemporary treatment protocols: A systematic review. Neurosci Biobehav Rev. 2015; 53: 108-20. PubMed Abstract | Publisher Full Text | Free Full Text | F1000 Recommendation

27. Richards S, Pui $\mathrm{CH}$, Gayon $\mathrm{P}$, et al.: Systematic review and meta-analysis of randomized trials of central nervous system directed therapy for childhood acute lymphoblastic leukemia. Pediatr Blood Cancer. 2013; 60(2): 185-95. PubMed Abstract | Publisher Full Text | Free Full Text

28. F Pui CH, Campana D, Pei D, et al:: Treating childhood acute lymphoblastic leukemia without cranial irradiation. N Engl J Med. 2009; 360(26): 2730-41. PubMed Abstract | Publisher Full Text | Free Full Text | F1000 Recommendation

29. F Vora A, Andreano A, Pui CH, et al:: Influence of Cranial Radiotherapy on Outcome in Children With Acute Lymphoblastic Leukemia Treated With Contemporary Therapy. J Clin Oncol. 2016; 34(9): 919-26.

PubMed Abstract | Publisher Full Text | Free Full Text | F1000 Recommendation

30. $\mathrm{F}$ Jacola LM, Krull KR, Pui $\mathrm{CH}$, et al.: Longitudinal Assessment of Neurocognitive Outcomes in Survivors of Childhood Acute Lymphoblastic Leukemia Treated on a Contemporary Chemotherapy Protocol. J Clin Oncol. 2016; 34(11): 1239-47.

PubMed Abstract | Publisher Full Text | Free Full Text | F1000 Recommendation

31. F Peters C, Schrappe M, von Stackelberg A, et al.: Stem-cell transplantation in children with acute lymphoblastic leukemia: A prospective international multicenter trial comparing sibling donors with matched unrelated donors-The ALL-SCT-BFM-2003 trial. J Clin Oncol. 2015; 33(11): 1265-74. PubMed Abstract | Publisher Full Text | F1000 Recommendation

32. Schrappe M, Hunger SP, Pui $\mathrm{CH}$, et al:: Outcomes after induction failure in childhood acute lymphoblastic leukemia. N Engl J Med. 2012; 366(15): 1371-81. PubMed Abstract | Publisher Full Text | Free Full Text

33. F Bhatia S, Landier W, Hageman L, et al: 6MP adherence in a multiracia cohort of children with acute lymphoblastic leukemia: a Children's Oncology Group study. Blood. 2014; 124(15): 2345-53.

PubMed Abstract | Publisher Full Text | Free Full Text | F1000 Recommendation

34. Eden T, Pieters R, Richards $S$, et al: Systematic review of the addition of vincristine plus steroid pulses in maintenance treatment for childhood acute lymphoblastic leukaemia - an individual patient data meta-analysis involving 5,659 children. Br J Haematol. 2010; 149(5): 722-33. PubMed Abstract | Publisher Full Text

35. Conter V, Valsecchi MG, Silvestri D, et al: Pulses of vincristine and dexamethasone in addition to intensive chemotherapy for children with intermediate-risk acute lymphoblastic leukaemia: a multicentre randomised trial. Lancet. 2007; 369(9556): 123-31. PubMed Abstract | Publisher Full Tex

36. F Clappier E, Grardel N, Bakkus M, et al:: IKZF1 deletion is an independen prognostic marker in childhood B-cell precursor acute lymphoblastic leukemia, and distinguishes patients benefiting from pulses during maintenance therapy: results of the EORTC Children's Leukemia Group study 58951. Leukemia. 2015: 29(11): 2154-61.

PubMed Abstract | Publisher Full Text | F1000 Recommendation

37. O'Connor D, Bate J, Wade R, et al:: Infection-related mortality in children with acute lymphoblastic leukemia: an analysis of infectious deaths on UKALL2003. Blood. 2014; 124(7): 1056-61.

PubMed Abstract | Publisher Full Text

38. Schmiegelow K, Attarbaschi A, Barzilai S, et al:: Consensus definitions of 14 severe acute toxic effects for childhood lymphoblastic leukaemia treatment: a Delphi consensus. Lancet Oncol. 2016; 17(6): e231-9. PubMed Abstract | Publisher Full Text

39. F Navarrete M, Rossi E, Brivio E, et al:: Treatment of childhood acute lymphoblastic leukemia in central America: a lower-middle income countries experience. Pediatr Blood Cancer. 2014; 61(5): 803-9. PubMed Abstract | Publisher Full Text | F1000 Recommendation

40. F Jabeen K, Ashraf MS, Iftikhar S, et al:: The Impact of Socioeconomic Factors on the Outcome of Childhood Acute Lymphoblastic Leukemia (ALL) Treatment in a Low/Middle Income Country (LMIC). J Pediatr Hematol Oncol. 2016; 38(8): 587-596.

PubMed Abstract | Publisher Full Text | F1000 Recommendation

41. Zaliova M, Hovorkova L, Vaskova M, et al.: Slower early response to treatment and distinct expression profile of childhood high hyperdiploid acute lymphoblastic leukaemia with DNA index $<1.16$. Genes Chromosomes Cancer 2016; 55(9): 727-37. PubMed Abstract | Publisher Full Tex

42. $\mathrm{F}$ Moorman AV: New and emerging prognostic and predictive genetic biomarkers in B-cell precursor acute lymphoblastic leukemia. Haematologica. 2016; 101(4): 407-16. PubMed Abstract | Publisher Full Text | Free Full Text | F1000 Recommendation
43. F Mullighan CG, Jeha S, Pei D, et al: Outcome of children with hypodiploid ALL treated with risk-directed therapy based on MRD levels. Blood. 2015; 126(26): 2896-9.

PubMed Abstract | Publisher Full Text | Free Full Text | F1000 Recommendation

44. F Mullighan CG, Su X, Zhang J, et al.: Deletion of IKZF1 and prognosis in acute lymphoblastic leukemia. N Engl J Med. 2009; 360(5): 470-80.

PubMed Abstract | Publisher Full Text | Free Full Text | F1000 Recommendation

45. Den Boer ML, van Slegtenhorst M, De Menezes RX, et al:: A subtype of childhood acute lymphoblastic leukaemia with poor treatment outcome: a genome-wide classification study. Lancet Oncol. 2009; 10(2): 125-34. PubMed Abstract | Publisher Full Text | Free Full Text

46. F Roberts KG, Pei D, Campana D, et al:: Outcomes of children with BCR$A B L 1-$ like acute lymphoblastic leukemia treated with risk-directed therapy based on the levels of minimal residual disease. J Clin Oncol. 2014; 32(27): 3012-20.

PubMed Abstract | Publisher Full Text | Free Full Text | F1000 Recommendation

47. F Schwab C, Ryan SL, Chilton L, et al:: EBF1-PDGFRB fusion in pediatric B-cell precursor acute lymphoblastic leukemia (BCP-ALL): genetic profile and clinical implications. Blood. 2016; 127(18): 2214-8.

PubMed Abstract | Publisher Full Text | F1000 Recommendation

48. F Roberts KG, Li Y, Payne-Turner D, et al:: Targetable kinase-activating lesions in Ph-like acute lymphoblastic leukemia. N Engl J Med. 2014; 371(11): 1005-15. PubMed Abstract | Publisher Full Text | Free Full Text | F1000 Recommendation

49. $\mathrm{F}$ Biondi A, Schrappe $\mathrm{M}$, De Lorenzo $\mathrm{P}$, et al: Imatinib after induction for treatment of children and adolescents with Philadelphia-chromosome-positive acute lymphoblastic leukaemia (EsPhALL): a randomised, open-label, intergroup study. Lancet Oncol. 2012; 13(9): 936-45.

PubMed Abstract | Publisher Full Text | Free Full Text | F1000 Recommendation

50. F Schultz KR, Carroll A, Heerema NA, et al: Long-term follow-up of imatinib in pediatric Philadelphia chromosome-positive acute lymphoblastic leukemia: Children's Oncology Group study AALL0031. Leukemia. 2014; 28(7): 1467-71. PubMed Abstract | Publisher Full Text | Free Full Text | F1000 Recommendation

51. Zaliova M, Fronkova E, Krejcikova K, et al.: Quantification of fusion transcript reveals a subgroup with distinct biological properties and predicts relapse in BCR/ABL-positive ALL: implications for residual disease monitoring. Leukemia. 2009; 23(5): 944-51.

PubMed Abstract | Publisher Full Text

52. Bleckmann K, Schrappe M: Advances in therapy for Philadelphia-positive acute lymphoblastic leukaemia of childhood and adolescence. Br J Haematol. 2016; 172(6): 855-69.

PubMed Abstract | Publisher Full Text

53. F Pui $\mathrm{CH}$, Pei D, Campana $\mathrm{D}$, et al.: Improved prognosis for older adolescents with acute lymphoblastic leukemia. J Clin Oncol. 2011; 29(4): 386-91. PubMed Abstract | Publisher Full Text | Free Full Text | F1000 Recommendation

54. Pichler $\mathrm{H}$, Reismüller $\mathrm{B}$, Steiner $\mathrm{M}$, et al:: The inferior prognosis of adolescents with acute lymphoblastic leukaemia (ALL) is caused by a higher rate of treatment-related mortality and not an increased relapse rate--a populationbased analysis of 25 years of the Austrian ALL-BFM (Berlin-Frankfurt-Münster) Study Group. Br J Haematol. 2013; 161(4): 556-65. PubMed Abstract | Publisher Full Text

55. F Sanjuan-Pla A, Bueno C, Prieto C, et al.: Revisiting the biology of infant t(4;11)/MLL-AF4 ${ }^{+}$B-cell acute lymphoblastic leukemia. Blood. 2015; 126(25): 2676-85

PubMed Abstract | Publisher Full Text | Free Full Text | F1000 Recommendation

56. F Buitenkamp TD, Izraeli S, Zimmermann M, et al:: Acute lymphoblastic leukemia in children with Down syndrome: a retrospective analysis from the Ponte di Legno study group. Blood. 2014; 123(1): 70-7. PubMed Abstract | Publisher Full Text | Free Full Text | F1000 Recommendation

57. Arber DA, Orazi A, Hasserjian R, et al.: The $\mathbf{2 0 1 6}$ revision to the World Health Organization classification of myeloid neoplasms and acute leukemia. Blood. 2016; 127(20): 2391-405. PubMed Abstract | Publisher Full Text

58. Bene MC, Bernier M, Casasnovas RO, et al.: The reliability and specificity of c-kit for the diagnosis of acute myeloid leukemias and undifferentiated leukemias. The European Group for the Immunological Classification of Leukemias (EGIL). Blood. 1998; 92(2): 596-9. PubMed Abstract

59. Bene MC, Porwit A: Acute leukemias of ambiguous lineage. Semin Diagn Pathol. 2012; 29(1): 12-8. PubMed Abstract | Publisher Full Text

60. Mejstrikova E, Volejnikova J, Fronkova E, et al.: Prognosis of children with mixed phenotype acute leukemia treated on the basis of consistent immunophenotypic criteria. Haematologica. 2010; 95(6): 928-35. PubMed Abstract | Publisher Full Text | Free Full Text

61. Kotrova M, Musilova A, Stuchly J, et al.: Distinct bilineal leukemia immunophenotypes are not genetically determined. Blood. 2016; pii: blood2016-07-725861.

PubMed Abstract | Publisher Full Text 
62. Rossi JG, Bernasconi AR, Alonso CN, et al.: Lineage switch in childhood acute leukemia: an unusual event with poor outcome. Am J Hematol. 2012; 87(9): 890-7. PubMed Abstract | Publisher Full Text

63. Slamova L, Starkova J, Fronkova E, et al:: CD2-positive B-cell precursor acute lymphoblastic leukemia with an early switch to the monocytic lineage. Leukemia. 2014; 28(3): 609-20.

PubMed Abstract | Publisher Full Text

64. F Clappier E, Auclerc MF, Rapion J, et al.: An intragenic ERG deletion is a marker of an oncogenic subtype of B-cell precursor acute lymphoblastic leukemia with a favorable outcome despite frequent IKZF1 deletions. Leukemia. 2014; 28(1): 70-7.

PubMed Abstract | Publisher Full Text | F1000 Recommendation

65. Hrusak O, Luks A, Janotova I, et al:: Acute Leukemias of Ambiguous Lineage; Study on 247 Pediatric Patients. Blood. 2015; 126(23): 252. Reference Source

66. F Irving JA: Towards an understanding of the biology and targeted treatment of paediatric relapsed acute lymphoblastic leukaemia. Br J Haematol. 2016; 172(5): 655-66.

PubMed Abstract | Publisher Full Text | F1000 Recommendation

67. Locatelli F, Schrappe M, Bernardo ME, et al:: How I treat relapsed childhood acute lymphoblastic leukemia. Blood. 2012; 120(14): 2807-16 PubMed Abstract | Publisher Full Text

68. Mullighan CG: Mutant PRPS1: a new therapeutic target in relapsed acute lymphoblastic leukemia. Nat Med. 2015; 21(6): 553-4. PubMed Abstract | Publisher Full Text

69. $F_{M a X}$, Edmonson M, Yergeau D, et al.: Rise and fall of subclones from diagnosis to relapse in pediatric B-acute lymphoblastic leukaemia. $\mathrm{Nat}$ Commun. 2015; 6: 6604 .

PubMed Abstract | Publisher Full Text | Free Full Text | F1000 Recommendation

70. F Meyer JA, Wang J, Hogan LE, et al:: Relapse-specific mutations in NT5C2 in childhood acute lymphoblastic leukemia. Nat Genet. 2013; 45(3): 290-4. PubMed Abstract | Publisher Full Text | Free Full Text | F1000 Recommendation

71. F Li B, Li H, Bai Y, et al.: Negative feedback-defective PRPS1 mutants drive thiopurine resistance in relapsed childhood ALL. Nat Med. 2015; 21(6): 563-71.

PubMed Abstract | Publisher Full Text | Free Full Text | F1000 Recommendation

72. F Mullighan CG, Zhang J, Kasper LH, et al:: CREBBP mutations in relapsed acute lymphoblastic leukaemia. Nature. 2011; 471(7337): 235-9. PubMed Abstract | Publisher Full Text | Free Full Text | F1000 Recommendation
73. F Parker C, Waters R, Leighton C, et al: Effect of mitoxantrone on outcome of children with first relapse of acute lymphoblastic leukaemia (ALL R3): an open-label randomised trial. Lancet. 2010; 376(9757): 2009-17.

PubMed Abstract | Publisher Full Text | Free Full Text | F1000 Recommendation

74. Eckert C, Henze G, Seeger K, et al.: Use of allogeneic hematopoietic stemcell transplantation based on minimal residual disease response improves outcomes for children with relapsed acute lymphoblastic leukemia in the intermediate-risk group. J Clin Oncol. 2013; 31(21): 2736-42. PubMed Abstract | Publisher Full Text

75. Krentz S, Hof J, Mendioroz A et al: Prognostic value of genetic alterations in children with first bone marrow relapse of childhood B-cell precursor acute lymphoblastic leukemia. Leukemia. 2013; 27(2): 295-304. PubMed Abstract | Publisher Full Text

76. F Eckert C, Hagedorn N, Sramkova L, et al.: Monitoring minimal residual disease in children with high-risk relapses of acute lymphoblastic leukemia: prognostic relevance of early and late assessment. Leukemia. 2015; 29(8): 1648-55

PubMed Abstract | Publisher Full Text | F1000 Recommendation

77. F Maude SL, Frey N, Shaw PA, et al.: Chimeric antigen receptor $\mathrm{T}$ cells for sustained remissions in leukemia. N Engl J Med. 2014; 371(16): 1507-17. PubMed Abstract | Publisher Full Text | Free Full Text | F1000 Recommendation

78. Maus MV, Grupp SA, Porter DL, et al.: Antibody-modified T cells: CARs take the front seat for hematologic malignancies. Blood. 2014; 123(17): 2625-35. PubMed Abstract | Publisher Full Text | Free Full Text

79. $F$ Brudno $\mathrm{JN}$, Kochenderfer $\mathrm{JN}$ : Toxicities of chimeric antigen receptor $\mathrm{T}$ cells: recognition and management. Blood. 2016; 127(26): 3321-30. PubMed Abstract | Publisher Full Text | Free Full Text | F1000 Recommendation

80. Gore L, Locatelli F, Zugmaier G, et al:: Initial Results from a Phase 2 Study of Blinatumomab in Pediatric Patients with Relapsed/Refractory B-Cell Precursor Acute Lymphoblastic Leukemia [abstract]. Blood. 2014; 124: 3703. Reference Source

81. $\mathrm{F}$ Schlegel $\mathrm{P}$, Lang $\mathrm{P}$, Zugmaier $\mathrm{G}$, et al.: Pediatric posttransplant relapsed/ refractory B-precursor acute lymphoblastic leukemia shows durable remission by therapy with the T-cell engaging bispecific antibody blinatumomab. by therapy with the T-cell engaging
Haematologica. 2014; 99(7): 1212-9. Haematologica. 2014; 99(7): 1212-9.
PubMed Abstract | Publisher Full Text | Free Full Text | F1000 Recommendation

82. $\mathrm{F}$ Kantarjian HM, DeAngelo DJ, Stelljes M, et al.: Inotuzumab Ozogamicin versus Standard Therapy for Acute Lymphoblastic Leukemia. N Engl J Med. 2016; 375(8): 740-53.

PubMed Abstract | Publisher Full Text | F1000 Recommendation 


\section{Open Peer Review}

\section{Current Peer Review Status:}

\section{Editorial Note on the Review Process}

Faculty Reviews are review articles written by the prestigious Members of Faculty Opinions. The articles are commissioned and peer reviewed before publication to ensure that the final, published version is comprehensive and accessible. The reviewers who approved the final version are listed with their names and affiliations.

\section{The reviewers who approved this article are:}

\section{Version 1}

\section{Stephen Sallan}

Dana-Farber Cancer Institute, Boston, MA, USA

Competing Interests: No competing interests were disclosed.

\section{Valentino Conter}

University of Milano-Biocca, Milan, Italy

Competing Interests: No competing interests were disclosed.

The benefits of publishing with F1000Research:

- Your article is published within days, with no editorial bias

- You can publish traditional articles, null/negative results, case reports, data notes and more

- The peer review process is transparent and collaborative

- Your article is indexed in PubMed after passing peer review

- Dedicated customer support at every stage

For pre-submission enquiries, contact research@f1000.com 